\title{
Herpes Zoster Oftalmikus Sinistra Diseminata dengan Infeksi Sekunder pada Anak
}

\author{
Patria Vittarina S, Alan R Tumbelaka, M. Hardjono Abdoerrachman
}

\begin{abstract}
Dilaporkan seorang anak perempuan berumur 6 tahun dengan herpes zoster oftalmikus sinistra diseminata yang mengalami infeksi sekunder. Diagnosis ditegakkan berdasarkan anammesis dan gambaran klinis yang khas berupa erupsi unilateral dan terbatas pada daerah kulit yang dipersarafi oleh satu ganglion sensorik. Komplikasi herpes zoster pada mata relatif tinggi terutama bila mengenai saraf trigeminus cabang nasosiliaris. Pasien

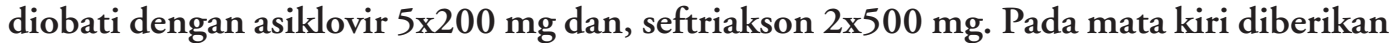
asiklovir salep mata, air mata buatan, xitrol dan sulfas atropin. Lesi kulit dikompres dengan larutan $\mathrm{NaCl}$ 0,9\% lalu diberikan salep asam fusidat. Evaluasi pada hari keempat perawatan menunjukkan vesikel sudah menghilang, terdapat krusta kuning kehitaman dan pada fase penyembuhan hari keduabelas, pada daerah perut terdapat bercak-bercak hipopigmentasi. Pemeriksaan mata menunjukkan adanya perbaikan, tanpa meninggalkan gejala sisa.
\end{abstract}

Kata kunci : Herpes zoster oftalmikus (HZO), diseminata, virus Varisela-Zoster (VVZ ).

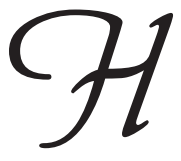
erpes zoster (HZ) adalah penyakit yang disebabkan oleh infeksi virus varisela zoster (VVZ) yang menyerang kulit dan mukosa. Infeksi ini merupakan reaktivasi infeksi laten VVZ yang terjadi setelah infeksi primer berupa varisela. ${ }^{1}$ Apabila yang terserang adalah ganglion trigeminal nervus $\mathrm{V}$ cabang oftalmikus maka dapat menyebabkan herpes zoster oftalmikus (HZO). ${ }^{1-3}$ Herpes zoster oftalmikus pertama-tama dilaporkan oleh Hutchinson pada tahun $1865 .{ }^{4}$ Penyakit ini terdapat di seluruh dunia dan timbul secara sporadis sepanjang tahun tanpa dipengaruhi oleh musim dan jenis kelamin. Pada umumnya ditemukan pada usia dewasa, sangat jarang terdapat pada anak. ${ }^{5,6}$

Patogenesis HZ belum seluruhnya diketahui, tetapi diduga bahwa selama terjadi varisela, VVZ berpindah

Dr. Patria Vittarina S: PPDS Ilmu Kesehatan Anak FKUI, Jakarta.

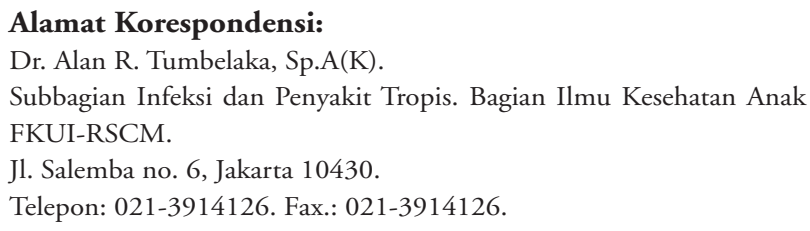

tempat dari lesi kulit dan permukaan mukosa ke ujung saraf sensoris dan diangkut secara sentripetal melalui serabut saraf sensoris ke ganglion sensoris. Selanjutnya terjadi infeksi laten, virus tersebut tidak lagi menular dan tidak bermultiplikasi, namun tetap mempunyai kemampuan untuk berubah menjadi infeksius. 5,6 Diduga insidens HZO tergantung pada faktor yang mempengaruhi hubungan antara virus dan pejamu, serta meningkat dengan bertambahnya usia. ${ }^{5}$ Berikut dilaporkan sebuah kasus HZO pada seorang anak perempuan, yang sangat jarang dijumpai.

\section{Kasus}

Seorang anak perempuan, 6 tahun, datang dengan keluhan utama timbul gelembung-gelembung berisi cairan di kulit wajah sebelah kiri. Sejak tujuh hari sebelumnya timbul gelembung-gelembung dengan dasar kemerahan berisi cairan jernih seperti luka bakar di dahi kiri, yang makin meluas ke mata, hidung dan mulut sebelah kiri, terasa perih dan gatal. Pasien merasa nyeri pada wajah kiri, serta demam. Keesokan harinya timbul kelainan kulit yang sama di perut dan tungkai 
kiri. Pasien belum pernah menderita sakit cacar air dan tidak didapatkan kontak dengan pasien cacar air. Riwayat kontak dengan penderita TB disangkal. Pada saat usia kehamilan 7 bulan ibu pasien menderita sakit cacar air. Riwayat persalinan normal, saat itu tidak didapatkan lesi kulit.

Pada pemeriksaan fisik didapatkan keadaan umum baik, status generalis tak ada kelainan. Status dermatologis, tampak di dahi kiri, kelopak mata, hidung dan pipi kiri tidak melewati garis tengah terdapat vesikel dan pustul berkelompok, sebagian tertutup krusta yang berwarna merah kehitaman di atas kulit yang eritematosa. Selain itu terdapat pus dan lesi ekskoriasi. Kelopak mata kiri terlihat edema dan tertutup. Pada dada dan perut terutama sebelah kanan, vesikel dan pustul dengan dasar eritematosa yang letaknya tersebar. Kelainan kulit yang sama terdapat pada paha kiri. Pada mata konjungtiva palpebra kemerahan edema, dan terjadi edema pada kornea. Konsultasi dengan Bagian Mata terdapat edema kornea, sesuai dengan adanya keratouveitis okuli sinistra yang disebabkan HZO. Hasil pemeriksaan darah lengkap LED, fungsi hati, ginjal, feses dan urinalisis dalam batas normal.

Ditegakkan diagnosis kerja herpes zoster oftalmikus diseminata yang mengalami infeksi sekunder. Pasien dirawat dan diobati laksana dengan seftriakson $2 \times 500$ $\mathrm{mg}$ intra vena, parasetamol $4 \times 250 \mathrm{mg}$ asiklovir tablet $5 \times 200 \mathrm{mg}$, asiklovir salep mata 5 kali sehari pada mata kiri dan air mata buatan setiap $1 \mathrm{jam}$, xitrol tetes mata 6 kali sehari pada mata kiri dan sulfas atropin tetes mata 3 kali sehari pada mata kiri, lesi kulit dikompres dengan $\mathrm{NaCl}$ 0,9\% lalu diberikan salep asam fusidat.

Pemeriksaan jumlah limfosit T total 2570 (62\%) (N:59,4-84,6\%). Pemeriksaan Imunoglobulin (Ig) G 1207 mg/dl (N:800-1800), Ig A 96,8 mg/dl (N:90450), IgM 249,2 (N:60-280), IgE $140 \mathrm{IU} / \mathrm{ml}(\mathrm{N}:<100)$.

Setelah perawatan hari keempat tidak lagi dijumpai vesikel, terdapat krusta kuning kehitaman yang mengecil dan dapat mengelupas pada hari kesembilan perawatan. Pada perawatan hari keduabelas pasien sembuh dengan meninggalkan bercak-bercak hipopigmentasi. Pemeriksaan mata menunjukkan adanya perbaikan klinis maka pasien dipulangkan

\section{Diskusi}

Pada umumnya diagnosis HZO sudah dapat dite- gakkan secara klinis tanpa banyak kesulitan. ${ }^{8}$ Pemeriksaan laboratorium hanya diperlukan untuk penelitian dan konfirmasi diagnosis. ${ }^{5,8}$ Keluhan yang dialami pasien sesuai dengan kepustakaan bahwa pada stadium praerupsi penyakit dimulai dengan gejala nyeri dan parestesi pada dermatom tertentu. Keluhan nyeri bervariasi dari perasaan gatal, kesemutan, panas, dan terasa nyeri seperti ditusuk-tusuk. Nyeri bersifat segmental dan dapat berlangsung terus menerus ataupun hilang timbul. Gejala prodomal lain seperti nyeri kepala, malaise, dan demam dapat terjadi pada $5 \%$ pasien terutama anak-anak dan biasanya terjadi 12 hari sebelum timbulnya erupsi. Pada masa prodomal ini kadang-kadang terjadi limfadenopati regional.,

Masa inkubasi HZ tidak diketahui karena tidak mungkin untuk menentukan saat terjadinya reaktivasi infeksi laten virus varisela-zoster. ${ }^{5}$ Herpes zoster merupakan penyakit yang terutama menyerang orang dewasa dan pasien imunokompromais, tetapi dapat juga mengenai bayi dan anak-anak. Beberapa penulis telah menemukan sejumlah kasus bayi di bawah umur 2 tahun tanpa riwayat varisela yang menderita herpes zoster, namun didapatkan riwayat varisela pada saat ibu hamil. Dalam hal ini dianggap bahwa paparan pertama dengan virus varisela zoster terjadi pada saat dalam kandungan dan gejala klinis yang pertama terlihat setelah lahir adalah herpes zoster; ${ }^{9}$ jadi adanya episode varisela sebelumnya merupakan suatu syarat untuk terjadi herpes zoster. ${ }^{5}$ Begitu juga pada pasien ini, kemungkinan telah terinfeksi varisela intrauterin saat ibu mengandung pasien dalam usia kehamilan 7 bulan.

Manifestasi klinis pada kasus ini seperti dalam kepustakaan disebutkan bahwa erupsi HZ khas, lokasi lesi kulit hampir selalu unilateral, tidak melewati garis tengah dan biasanya terbatas pada daerah kulit yang dipersarafi oleh satu ganglion sensorik. ${ }^{5}$ Apabila disertai dengan lebih dari 20 vesikel yang timbul pada kulit di luar dermatom yang terkena maka disebut $\mathrm{HZ}$ diseminata. ${ }^{10}$ Pada pasien imunokompeten, resiko HZ menjadi diseminata sangat kecil sedangkan pada pasien imunokompromais mendekati 40\%. ${ }^{11}$ Erupsi dimulai sebagai makula eritematosa dan papula, kemudian lesi kulit berkembang menjadi vesikel dalam 12-24 jam; vesikel dapat berkelompok atau berkonfluensi. Kelopak mata bengkak, ptosis dan sering tampak konjungtiva hiperemi. Vesikel akan menjadi pustul pada hari ketiga dan akan mengering membentuk krusta pada hari sakit ke 7-10, dan krusta dapat bertahan sampai 2-3 minggu. 5,7 
Pada kasus ini timbul komplikasi infeksi sekunder yang ditandai dengan adanya pus pada lesi kulit. Disamping itu, pada kasus ini juga terdapat vesikel pada sisi ujung hidung (Hutchinson's sign) yang menunjukkan terlibatnya saraf trigeminus cabang nasosiliaris dengan manifestasi sebagai keratouveitis. Hal ini sesuai dengan kepustakaan yang menyebutkan bahwa adanya vesikel pada sisi ujung hidung (Hutchinson's sign) menunjukkan terlibatnya cabang nasosiliaris dan kemungkinan besar mata akan terkena juga., ${ }^{3,4,12}$ Komplikasi mata terjadi pada $50-71 \%$ pasien HZO. ${ }^{4}$ Konjungtivitis merupakan komplikasi yang sering terjadi dan biasanya sembuh sendiri. ${ }^{4,12}$ Herpes zoster oftalmikus mempunyai angka komplikasi yang relatif tinggi terutama bila mengenai cabang nasosiliaris, karena infeksi dapat langsung ke struktur intra okuli. Komplikasi ini dapat berupa retraksi, ptosis paralitik, keratitis akut, skleritis, uveitis, glaukoma sekunder, palsiokulomotor, korioretinitis dan neuritis optika. Gangguan sensasi dari kornea hampir selalu didapat dan bila berat dapat menyebabkan keratitis neurotropik dan ulserasi kronik. Meskipun jarang, dapat terjadi infeksi sekunder oleh bakteri dan dapat menyebabkan terjadinya panoftalmitis yang memerlukan tindakan enukleasi mata. ${ }^{4,12}$ Terdapatnya genom virus yang hampir selalu disertai ekspresi gen atau replikasi virus lambat merupakan penyebab terjadinya panoftalmitis dan keratouveitus kronik rekuren pada kasus $\mathrm{HZO}{ }^{2}$

Neuralgia pasca herpetika merupakan komplikasi yang sering terjadi pada HZO yaitu pada $17-20 \%$ kasus, namun komplikasi ini jarang timbul di bawah umur 40 tahun. ${ }^{4,5}$ Demikian pula pada pasien ini tidak terdapat neuralgia pasca herpetika karena usia pasien yang masih muda.

Pasien mendapat pengobatan asiklovir dan antibiotik sistemik, sedangkan infeksi sekunder dan kelainan mata diberikan kompres dan antibiotik lokal. Sesuai pedoman pengobatan HZ, diberikan asiklovir baik sistemik maupun topikal. Sebaiknya diberi terapi kombinasi dengan asiklovir topikal pada awal perjalanan penyakit dan kortikosteroid topikal pada fase lanjut (bila inflamasi sekunder dominan). Disamping itu diberikan terapi topikal pada kulit berupa bedak tabur untuk vesikel atau bula yang tidak pecah serta kompres sedangkan antibiotik lokal diberikan apabila vesikel sudah pecah. ${ }^{13,14,15}$

Pencegahan dengan imunisasi varisela akan bermanfaat jika diberikan pada tahap awal penularan. Imunisasi secara pasif, yaitu dengan pemberian imunoglobulin zoster atau imunoglobulin varisela zoster. Pemberian imunoglobulin dilakukan dalam 72 jam pertama setelah terpapar dan ditujukan terhadap pasien defisiensi imun dengan berbagai sebab dan bayi yang lahir dari ibu yang menderita varisela. Sedangkan imunisasi aktif berupa vaksin yang mengandung virus yang telah dilemahkan diberikan pada anak dengan risiko tinggi, anak yang dirawat di rumah sakit dan mempunyai risiko terpapar varisela, atau anak normal dengan indikasi khusus. ${ }^{7}$

Pencegahan perlu dilakukan pada adik pasien, namun oleh karena keterbatasan biaya dan ketersediaan vaksin, maka vaksinasi varisela tidak diberikan pada adiknya dan ibu dianjurkan untuk menjauhkan adiknya dari pasien.

Pada umumnya HZ merupakan penyakit yang tidak fatal, termasuk golongan penyakit swasirna dan mempunyai prognosis yang baik. Pada kasus imunokompromais, varisela dapat menjadi berat dan lebih sering terjadi komplikasi. Walaupun demikian, kematian lebih sering disebabkan oleh penyakit yang mendasarinya. ${ }^{5,7}$ Pada pasien ini penyakit dapat sembuh sempurna dengan meninggalkan bercak hipopigmentasi.

\section{Daftar Pustaka}

1. Handoko RP. Penyakit virus. Dalam: Djuanda A, penyunting. Buku Ajar Ilmu Penyakit Kulit dan Kelamin; edisi ke-3, Jakarta: Balai Penerbit, 1999. h. 107-9.

2. Wenkel H, Rummelt V. Detection of Varicella Zoster Virus DNA and Voral Antigen in Human Eyes after Herpes Zoster Ophthalmicus. Ophthalmology 1998; 105:1323-30.

3. Liesegang TJ. The varicella zoster virus: Systemic and occular features. J Am Acad Dermatol 1984; 11:16591.

4. Rober I, Laibson P. Herpes zoster opthalmicus. Dalam: Leibowitz HM, penyunting. Corneal Disorders Clinical Diagnosis and Management. Philadelphia: WB Saunders, 1984. h. 409-19.

5. Oxman MN, Alani R. Varicella and herpes zoster. Dalam: Fitzpatrick TB, Eizen AZ, penyunting. Dermatology in General Medicine; edisi ke-4. New York: Mc Graw Hill, 1993. h. 2534-72.

6. Martin GM, Lawrence RS. Herpes zoster. Dalam: Behrman RE, Vaughn VC, Nelson WE, penyunting. Textbook of Pediatrics; edisi ke-14, Philadelphia: WB Saunders, 2000. h. 975-7.

7. Gershon A, Russa P. Varicella-zoster infections. Dalam: Krugman S, Katz SL, Gershon A, penyunting. Infectious Diseases of Children; edisi ke-9, St Louis; Mosby, 
1992. h. 587-614.

8. Wiryadi BE. Diagnosis herpes zoster. Disampaikan pada Diskusi Panel Penatalaksanaan Infeksi Virus VariselaZoster, Jakarta, 2 Februari, 1994.

9. Brunell PA. Varicella-zoster infections. Dalam: Feigin $\mathrm{RD}$, Cherry JD, penyunting pediatric infectious Diseases: edisi ke-3. Philadelphia: WB Saunders, 1992. h. 1587-91.

10. Stratman E. Visceral zoster as presenting treatment of disseminated herpes zoster. JAm Ac Dermatol 2002; 46:771-4.

11. Mc Crary ML, Severson J, Trying SK. Varicella zoster virus. J Am Acad Derematol 1999; 41:1-14.

12. Karbassi M, Raizman MB, Schuman JS. Herpes zoster opthalmicus. Surv Ophthalmol 1992; 36:395-410.

13. Pusponegoro EHD. Pengobatan herpes zoster. Disampaikan pada Diskusi Panel Penatalaksanaan Infeksi Virus Varisela-Zoster, Jakarta, 2 Februari, 1994.

14. Kelompok Studi Herpes Indonesia. Penatalaksanaan kelompok penyakit Herpes di Indonesia Jakarta: Kelompok Studi Herpes Indonesia 1997. h. 35-45.

15. Lily $S$, Indrarini. Penatalaksanaan infeksi virus varisela zoster pada bayi dan anak. MDVI 2000; 45:65S-72S. 